\title{
DEPOLIMERISASI KARAGINAN MURNI DENGAN HIDROGEN PEROKSIDA DAN AKSELERASI GELOMBANG ULTRASONIK
}

\author{
Uju $^{1,2 *}$, Joko Santoso ${ }^{1}$, Ianaegea Randioko Hans Raprap ${ }^{1}$ \\ ${ }^{1}$ Departemen Teknologi Hasil Perairan, Fakultas Perikanan dan Ilmu Kelautan, \\ Institut Pertanian Bogor \\ ${ }^{2}$ Surfactant and Bioenergy Research Center, Bogor Agricultural University \\ Institut Pertanian Bogor, Kampus IPB Darmaga, Jalan Agatis, Bogor 16680 Jawa Barat \\ Telepon (0251) 8622909-8622906, Faks. (0251) 8622915 \\ ^Korespodensi: ujusadi@gmail.com \\ Diterima: 24 Januari 2018/ Disetujui: 23 April 2018
}

Cara sitasi: Uju, Santoso J, Raprap IRH. 2018. Depolimerisasi karaginan murni dengan hidrogen peroksida dan akselerasi gelombang ultrasonik. Jurnal Pengolahan Hasil Perikanan Indonesia. 21(1): 156-166.

\begin{abstract}
Abstrak
Karaginan dengan bobot molekul lebih dari $100 \mathrm{kDa}$ memiliki tingkat kelarutan yang kecil. Karaginan berbobot molekul rendah dapat diperoleh melalui depolimerisasi secara kimia, fisika, enzimatis dan radiasi. Tujuan penelitian ini adalah untuk menentukan kombinasi terbaik $\left(\mathrm{H}_{2} \mathrm{O}_{2}\right)$ dan suhu ultrasonikasi untuk membuat karaginan berbobot molekul rendah dari karaginan murni, serta membandingkan karakteristik perlakuan terpilih dengan kontrol dan karaginan murni. Konsentrasi $\mathrm{H}_{2} \mathrm{O}_{2}$ yang digunakan untuk depolimerisasi adalah $2 \%, 4 \%$ atau $6 \%(\mathrm{~b} / \mathrm{v})$ dan suhu ultrasonikasi adalah $40^{\circ} \mathrm{C}$ atau $60^{\circ} \mathrm{C}$. Penggunaan konsentrasi dan suhu ultrasonikasi berpengaruh terhadap karakteristik deplimerisasi karaginan munrni yang dihasilkan. Perlakuan terpilih diperoleh dari karaginan yang di-depolimerisasi dengan $\mathrm{H}_{2} \mathrm{O}_{2} 6 \%$ dan suhu ultrasonikasi $60^{\circ} \mathrm{C}$ dengan hasil rendemen $78,83 \pm 0,79 \%$, viskositas $1,75 \pm 0,10 \mathrm{cP}$ dan bobot molekul $4,47 \pm 2,88 \mathrm{kDa}$. Perlakuan ini menghasilkan karaginan depolimerisasi dengan gugus fungsional yang sangat berbeda dengan perlakuan lainnya yang menunjukkan proses depolimerisasi telah terjadi.
\end{abstract}

Kata kunci: depolimerisasi karaginan, $\mathrm{H}_{2} \mathrm{O}_{2}$, karaginan berbobot molekul rendah, ultrasonikasi

\section{Depolymerisation of Carrageenan with Hydrogen Peroxide and Accelerated by Ultrasonic Wave}

\begin{abstract}
Carrageenan with molecular weight more than $100 \mathrm{kDa}$ has low solubility. Low molecular weight carrageenan can be obtained by depolymerisation using chemical, physics, enzymatic and radiation. Research aim was to determine the best combination of hydrogen peroxide $(\mathrm{H} 2 \mathrm{O} 2)$ and ultrasonication temperature to obtain oligosaccharides with low molecular weight from refined carrageenan. Concentrations of $\mathrm{H} 2 \mathrm{O} 2$ were $2 \%, 4 \%$ and $6 \%(\mathrm{w} / \mathrm{v})$ respectively, while temperatures of ultrasonication were $40{ }^{\circ} \mathrm{C}$ and $60{ }^{\circ} \mathrm{C}$. The concentration of $\mathrm{H} 2 \mathrm{O} 2$ and temperature of ultrasonication effected the charactersitics of depolymerized refined carrageenan. The elected of depolymerized refined carrageenan was obtained from the treatment of $6 \% \mathrm{H} 2 \mathrm{O} 2$ and ultrasonication temperature $60{ }^{\circ} \mathrm{C}$ with yield $78,83 \% \pm 0,79$; viscosity $1.75 \mathrm{cP} \pm 0.10$ and molecular weight $4.47 \mathrm{kDa} \pm 2.88$. The treatment produced the depolymerized refined carrageenan with its functional group of carrageenan was very different compared from other treatments which showed depolymerisation has occurred.
\end{abstract}

Keywords: carrageenan degradation, $\mathrm{H} 2 \mathrm{O} 2$, low molecular weight carrageenan, ultrasonication 


\section{PENDAHULUAN}

Indonesia merupakan salah satu wilayah perairan coral triangle dari habitat enam spesies rumput laut yang potensial antara lain Gracillaria, Gellidium, Eucheuma, Hypnea, Sargassum dan Turbinaria. Produksi rumput laut Indonesia tahun 2015 sebanyak 10,8 juta ton, nilai tersebut meningkat lebih dari tiga kali lipat produksi rumput laut pada tahun 2010 sebesar 3,5 juta ton (United Nation Commodity Trade Statistics Database 2017). Produksi rumput laut Indonesia yang melimpah membuat komoditas tersebut menjadi penopang perekonomian nasional melalui peningkatan penerimaan devisa negara. Rumput laut sebagian besar masih diekspor dalam bentuk bahan mentah berupa rumput laut kering karena hasil pascapanen rumput laut.

Hasil pascapanen rumput laut salah satunya yaitu karaginan. Karaginan merupakan senyawa hidrokoloid hasil metabolisme primer rumput laut jenis Kappaphycus alvarezii termasuk dalam kelas Rhodopyceae yang dikenal dengan nama dagang Eucheuma cottonii (Milani dan Maleki 2012). Hidrokoloid karaginan termasuk polimer dalam grup fikokoloid ester sulfat larut air yang tersusun dari ikatan $\alpha-1,3$ dan $\beta$-1,4 D-galaktopiranosa dengan bobot molekul lebih dari $100 \mathrm{kDa}$ (Angka et al. 2000). Hidrokoloid tersebut berfungsi sebagai pemekat, pengemulsi, dan penstabil serta memiliki kemampuan untuk membentuk gel secara thermoreversible atau gel menjadi kental saat didinginkan dan kembali menjadi cair saat dipanasakan (Diharmi et al. 2011).

Karaginan menjadihidrokoloid serbaguna yang dapat digunakan dalam berbagai bidang. Industri pangan menggunakan karaginan sebagai penstabil yang ideal pada industri susu (Pereira et al. 2009), bahan tambah pada pembuatan permen jelly gelatin kulit ikan cucut (Suptijah et al. 2013), serta bahan tambah pada pembuatan kamaboko ikan kurisi (Agustin 2012). Penambahan gliserol dan karaginan pada pembuatan edible film dari pati buah lindur (Jacoeb et al. 2014). Industri kosmetik menggunakannya sebagai gelling agent (pembentuk gel) atau binding agent
(Ega et al. 2016). Pomin et al. (2010) melaporkan bahwa karaginan dalam bidang medis digunakan karena memiliki senyawa yang bersifat elektronegatif dan kerapatan muatan antaraester sulfat yang memungkinkan terjadinya interaksi elektrostatik dengan protein secara spesifik yang menyebabkan munculnya fungsi aktivitas biologi senyawa tersebut.

Karaginan dengan bobot molekul yang besar (lebih dari $100 \mathrm{kDa}$ ) memiliki tingkat kelarutan kecil sehingga aplikasinya dalam bidang medis dan kosmetika menjadi terbatas. Hal tersebut sesuai dengan yang dilaporkan Haijin et al. (2003) bahwa karaginan yang memiliki bobot molekul rendah dari hasil depolimerisasi ditemukan adanya aktivitas anti-tumor. Hasil penelitian tersebut menunjukkan perlunya dilakukan penelitian mengenai depolimerisasi karaginan, sehingga dapat diaplikasikan ke berbagai bidang, terutama dalam bidang kesehatan.

Penelitian tentang pengembangan metode depolimerisasi karaginan telah banyak dilakukan, antara lain metode depolimerisasi menggunakan asam klorida (Kalitinik et al. 2013; Yu et al. 2002; Yuan dan Song 2005), enzim karagenase (Kalitinik et al. 2013; Haijin et al. 2003) dan radiasi (Abad et al. 2009). Siregar et al. (2016) melaporkan bahwa $\mathrm{H}_{2} \mathrm{O}_{2}$ dapat efektif untuk depolimerisasi polisakarida karaginan. Prinsip depolimerisasi polisakarida dengan $\mathrm{H}_{2} \mathrm{O}_{2}$ adalah berdasarkan pada pembentukan radikal hidroksil reaktif. Hidrogen peroksida merupakan oksidator kuat yang dapat menyerang ikatan glikosidik pada polisakarida sehingga menyebabkan peningkatan jumlah rantai polimer dan penurunan bobot molekul pada produk polisakarida yang dihasilkan (Sun et al. 2009).

Gelombang ultrasonik telah banyak dilaporkan dapat digunakan untuk mempercepat proses ekstraksi proses depolimerisasi (Fuadi 2012, Ratnawati et al. 2016; Sanchez et al. 2013). Penggunaan kombinasi antara penggunaan $\mathrm{H}_{2} \mathrm{O}_{2}$ dan ultrasonikasi diharapkan dapat membuat karaginan dengan bobot molekul rendah dengan cara yang lebih efisien. Penelitian ini bertujuan menentukan 
kombinasi terbaik $\mathrm{H}_{2} \mathrm{O}_{2}$ dan suhu ultrasonikasi untuk membuat karaginan berbobot molekul rendah dari karaginan murni, serta membandingkan karakteristik perlakuan terpilih dengan kontrol dan karaginan murni.

\section{BAHAN DAN METODE Bahan dan Alat}

Bahan utama yang digunakan adalah karaginan murni yang didapat dari CV Ocean Fresh Bogor. Bahan lain yang digunakan adalah hidrogen peroksida MERCK ${ }^{\oplus}\left(\mathrm{H}_{2} \mathrm{O}_{2}\right)$, akuades dan isopropil alkohol MERCK ${ }^{\oplus}$ (IPA). Alat utama yang digunakan pada penelitian ini adalah timbangan analitik (Sartorius TE 64, US), termometer, kompor listrik, hot plate (SCILOGEX MS-H280-P50, US), nilon 100 mesh, oven mekanik (300 Watt), ultrasonic processor (Cole Palmer 130Watt 20kHz, CN), viskometer (Gilmond GV 2200, US), oven (Yamato DV 41, JP), tanur (Yamato FM 38, JP) dan Fourier Transform Infra Red Spectroscopy/ FTIR (Bruker Tensor 37, US).

\section{Metode Penelitian}

Penelitian ini diawali dengan mengkarakterisasi karaginan murni yang meliputi parameter viskositas (instruksi vendor seperti yang dideskripsikan oleh Uju 2005), prediksi model bobot molekul (Walstra 2003), kadar sulfat (FMC Corp. 1977), dan kadar abu tak larut asam (FMC Corp. 1977). Tahap kedua yaitu depolimerisasi karaginan yang mengacu pada Li et al. (2010) dan Savitrietal. (2014) dengan beberapa modifikasi. Depolimerisasi dilakukan dengan $\mathrm{H}_{2} \mathrm{O}_{2}$ pada konsentrasi 2\%, 4\% dan 6\% (b/v). Proses depolimerisasi tersebut dilakukan dengan ultrasonikasi pada suhu $40^{\circ} \mathrm{C}$ dan $60^{\circ} \mathrm{C}$. Tahap ketiga yaitu menentukan perlakuan terpilih dengan mempertimbangkan parameter depolimerisasi rendemen, viskositas dan bobot molekul. Tahapke empat yaitu dengan membandingkan perlakuan terpilih dengan perlakuan kontrol dan karaginan murni. Parameter yang dibandingkan yaitu kadar abu tak larut asam, kadar sulfat dan analisis gugus fungsi.

\section{Depolimerisasi karaginan murni}

Proses depolimerisasi diawali dengan menimbang karaginan $10 \mathrm{~g}$ kemudian ditambahkan dengan $500 \mathrm{~mL}$ akuades untuk memperoleh larutan karaginan 2\% (b/v). Larutan tersebut ditambahkan $500 \mathrm{~mL} \mathrm{H}_{2} \mathrm{O}_{2}$ pada konsentrasi $2 \%, 4 \%$ atau $6 \%$. Larutan dipanaskan dengan hotplate secara bertahap pada suhu $40^{\circ} \mathrm{C}$ atau $60^{\circ} \mathrm{C}$ selama 20 menit. Proses depolimerisasi tersebut diakselerasi dengan ultrasonikasi pada frekuensi $20 \mathrm{kHz}$ dan daya 130 Watt. Karaginan yang diberi perlakuan tersebut didinginkan pada suhu ruang kemudian dipresipitasi dengan IPA pada rasio IPA:larutan 3:1 (v/v). Karaginan yang terpresipitasi disaring dengan kain nilon 100 mesh kemudian dikeringkan dalam oven pada suhu $60^{\circ} \mathrm{C}$ selama $12 \mathrm{jam}$.

\section{Penentuan perlakuan terpilih}

Karaginan hasil depolimerisasi yang diperoleh kemudian dilakukan karakterisasi untuk menentukan perlakuan terpilih. Karakterisasi yang dilakukan meliputi rendemen, viskositas dan bobot molekul. Hasil karakteristik tersebut kemudian dibandingkan dengan perlakuan kontrol dan karaginan murni.

\section{Karakterisasi perlakuan terpilih}

Karakteristik karaginan perlakuan terpilih dari hasil depolimerisasi (KP) dibandingkan dengan karakteristik karaginan murni tanpa depolimerisasi (KM) dan karaginan hasil depolimerisasi yang hanya menggunakan ultrasonikasi pada suhu suhu $60^{\circ} \mathrm{C}$ dan dengan karaginan hasil depolimerisasi yang menggunakan $\mathrm{H}_{2} \mathrm{O}_{2} 6 \%$ pada suhu $60^{\circ} \mathrm{C}(\mathrm{KK})$. Perbandingan perlakuan tersebut kemudian dilakukan analisis yaitu kadar abu tak larut asam, kadar sulfat dan analisis gugus fungsi.

\section{Analisis Data}

Data yang dianalisis pada penelitian ini terbagi menjadi dua. Rancangan percobaan pertama yang digunakan yaitu rancangan acak lengkap (RAL) dua faktorial untuk pemilihan perlakuan terpilih pada parameter 
Tabel 1 Karakteristik awal karaginan murni

(Table 1 Characteristics of pure carrageen)

\begin{tabular}{lcl}
\hline Karakteristik/Characteristics & Karaginan/ Carrageenan & Standar/Standard \\
\hline Sulfat/Sulphates $(\%)$ & $18.59 \pm 0.11$ & $15-40^{\star}$ \\
Abu tak larut asam/Acid -insoluble ash (\%) & $0.18 \pm .0 .01$ & Maks. $1^{\star}$ \\
Viskositas/Viscosity (cP) & $30.87 \pm 0.25$ & Min. $5^{\star}$ \\
Bobot molekul/Molecular weight $(\mathrm{kDa})$ & $190.70 \pm 0.93$ & $100-500^{* *}$ \\
\hline Sumber: ${ }^{\star} \mathrm{FAO}(2007),{ }^{*} \mathrm{FAO}(1990)$ & &
\end{tabular}

rendemen, viskositas dan bobot molekul. Rancangan percobaan kedua yang digunakan setelah mendapatkan perlakuan terpilih adalah rancangan acak lengkap satu faktor. Rancangan percobaan ini dilakukan pada parameter analisis kadar abu tak larut asam dan kadar sulfat.

\section{HASIL DAN PEMBAHASAN Karakteristik Karaginan Murni}

Karakterisasi terhadap sampel karaginan murni sebagai bahan baku yang akan didepolimerisasi meliputi karakterisasi secara kimiawi dan fisika yang meliputi viskositas, kadar sulfat, abu tak larut asam, dan bobot molekul. Hasil karakterisasi bahan baku tersebut dapat dilihat pada Tabel 1 .

Kadar sulfat karaginan murni yang didapat sebesar 18,59\%. Hasil tersebut tidak berbeda jauh dengan yang dilaporkan Distantina (2013) yaitu $18,60 \%$. Kadar sulfat tersebut sudah memenuhi standar kadar sulfat yang ditetapkan FAO (2007) yaitu 15-40\%. Kadar abu tak larut asam yang didapat dari hasil penelitian adalah $0,18 \%$, yang juga sudah sesuai dengan standar FAO (2007) yakni maksimal $1 \%$.

Karakteristik fisik karaginan murni yang terdiri dari viskositas dan bobot molekul. Hasil viskositas karaginan murni yang didapat sebesar 30,87 cP. Nilai viskositas karaginan ini telah memenuhi persyaratan minimum FAO (2007) minimal 5 cP. Parameter fisik yang kedua yaitu bobot molekul. Nilai bobot molekul karaginan murni yang diperoleh pada penelitian ini adalah 190,70 $\mathrm{kDa}$. Nilai bobot molekul tersebut telah memenuhi standar persyaratan yang ditetapkan oleh FAO (1990) maksimal sebesar $500 \mathrm{kDa}$.

\section{Rendemen Karaginan Hasil Depolimerisasi}

Rendemen menjadi salah satu indikator proses dan kualitas suatu

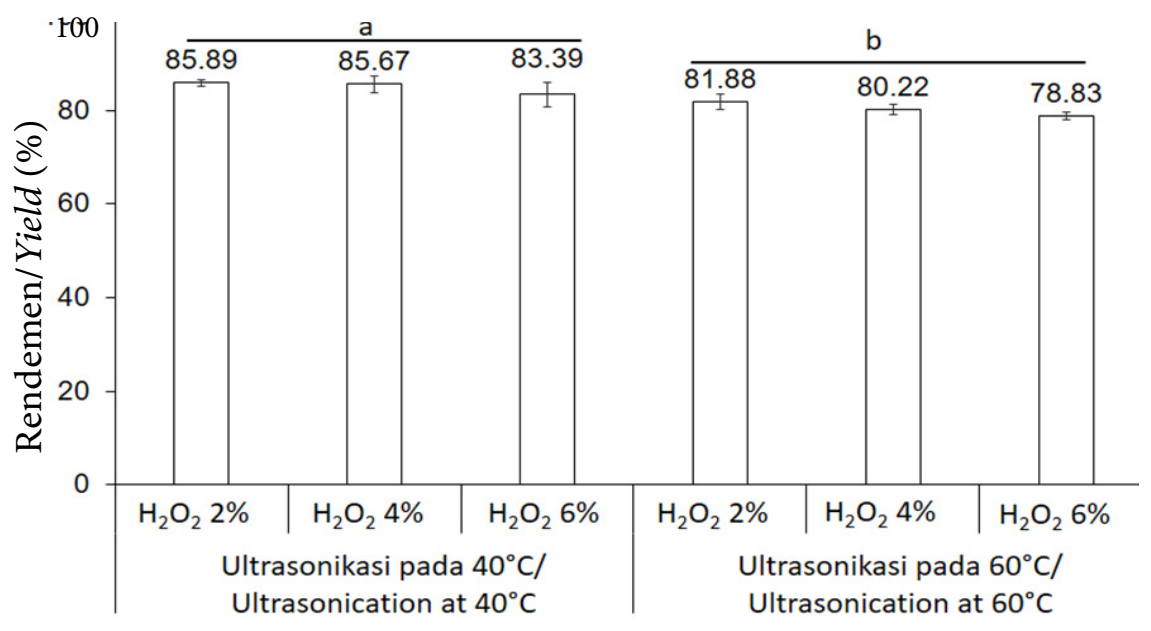

Gambar 1 Pengaruh suhu ultrasonikasi dan konsentrasi hidrogen peroksida terhadap rendemen karaginan yang depolimerisasi.

(Figure 1 Effect of ultrasonic temperature and hydrogen peroxide concentration on depolymerized carrageen recovery). 
proses. Rendemen karaginan hasil depolimerisasi karaginan dihitung dengan cara membandingkan antara berat padatan karaginan yang dihasilkan dari proses depolimerisasi terhadap bobot karaginan murni. Rendemen hasil depolimerisasi karaginan dapat dilihat pada Gambar 1.

Hasil analisis ragam menunjukkan bahwa rendemen depolimerisasi karaginan dipengaruhi oleh suhu ultrasonikasi berbeda $(\mathrm{p}<0,05)$, sedangkan perlakuan konsentrasi $\mathrm{H}_{2} \mathrm{O}_{2}$ dan interaksi antara suhu ultrasonikasi dan konsentrasi $\mathrm{H}_{2} \mathrm{O}_{2}$ tidak mempengaruhi nilai rendemen yang dihasilkan ( $p>0,05)$. Hasil uji lanjut Duncan menunjukkan rendemen karaginan hasil depolimerisasi dengan perlakuan suhu ultrasonikasi $40^{\circ} \mathrm{C}$ berbeda nyata dengan karaginan hasil depolimerisasi menggunakan perlakuan suhu ultrasonikasi $60^{\circ} \mathrm{C}$. Menurut Fuadi (2012), gelombang ultrasonik yang digunakan dalam proses ekstraksi dapat meningkatkan nilai rendemen dengan tingkat efisiensi waktu mencapai 50\%. Ratnawati et al. (2016) menyatakan perlakuan suhu tinggi pada ultrasonikasi dapat menyebabkan uap dari pelarut masuk ke dalam rongga kavitasi yang terbentuk sehingga menghambat proses depolimerisasi sehingga rendemen yang dihasilkan rendah.

\section{Karakteristik Viskositas Karaginan Hasil Depolimerisasi}

Viskositas merupakan ukuran kekentalan suatu zat cair yang menyatakan besar kecilnya tahanan terhadap gesekan antara molekulmolekul zat cair dengan gaya kohesi pada zat cair tersebut. Viskositas karaginan hasil depolimerisasi dapat dilihat pada Gambar 2.

Viskositas karaginan hasil depolimerisasi tertinggi terdapat pada perlakuan $\mathrm{H}_{2} \mathrm{O}_{2} 2 \%$ dengan suhu ultrasonikasi $40^{\circ} \mathrm{C}$ sebesar $8,04 \mathrm{cP}$ sedangkan viskositas terendah terdapat pada perlakuan $\mathrm{H}_{2} \mathrm{O}_{2} 6 \%$ dengan suhu ultrasonikasi $60^{\circ} \mathrm{C}$ sebesar $1,75 \mathrm{cP}$. Hasil analisis ragam menunjukkan bahwa viskositas karaginan hasil depolimerisasi dipengaruhi oleh perlakuan ultrasonik pada suhu ultrasonikasi berbeda, perlakuan konsentrasi $\mathrm{H}_{2} \mathrm{O}_{2}$ yang berbeda serta interaksi keduanya $(\mathrm{p}<0,05)$. Hasil uji lanjut Duncan menunjukkan viskositas karaginan hasil depolimerisasi dengan kombinasi perlakuan $\mathrm{H}_{2} \mathrm{O}_{2} 6 \%$ dan suhu ultrasonikasi $60^{\circ} \mathrm{C}$ tidak berbeda nyata dengan perlakuan $\mathrm{H}_{2} \mathrm{O}_{2} 4 \%$ dan suhu ultrasonikasi $60^{\circ} \mathrm{C}$ namun berbeda nyata terhadap perlakuan lainnya.

Hasil yang didapat menunjukkan semakin tinggi suhu perlakuan maka semakin rendah nilai viskositas karaginan tersebut. Hasil ini

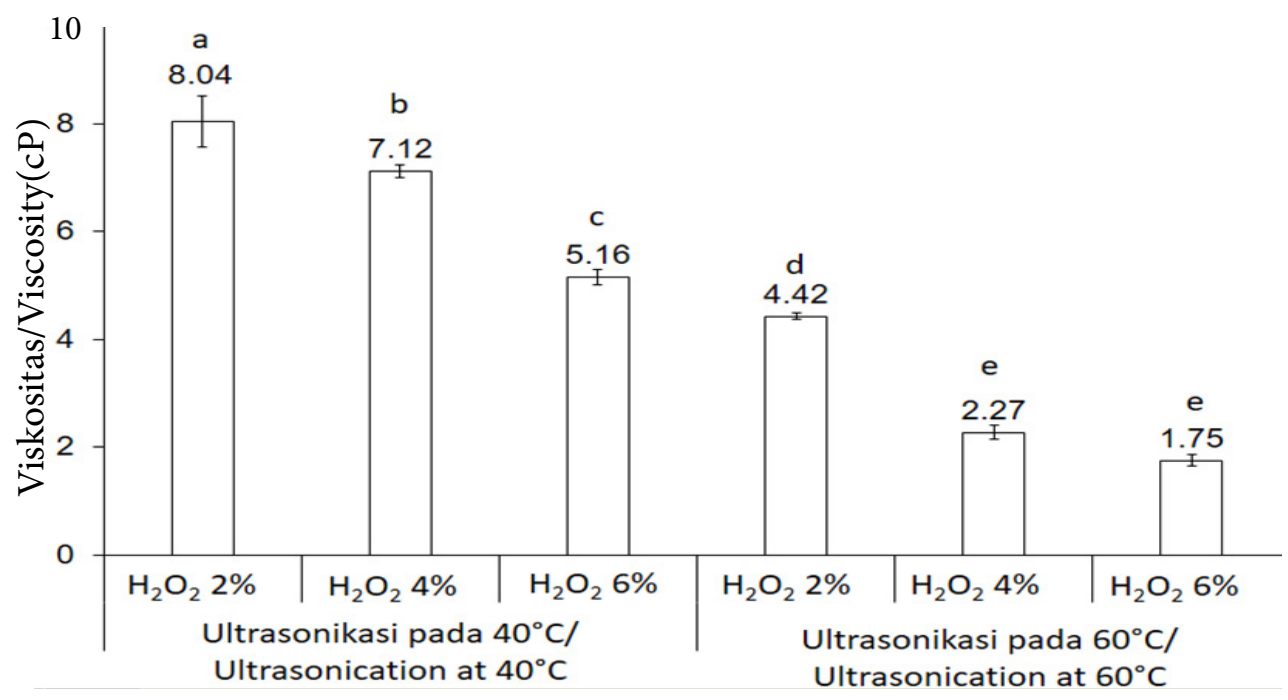

Gambar 2 Pengaruh suhu ultrasonikasi dan konsentrasi hidrogen peroksida terhadap viskositas karaginan yang depolimerisasi.

(Figure 2 Effect of ultrasonic temperature and hydrogen peroxide concentration on the depolymerized carcinogen viscosity). 
serupa dengan yang dilaporkan Ega et al. (2016) dan Sanchez et al. (2013) bahwa viskositas larutan menurun seiring peningkatan suhu akibat terjadi depolimerisasi dari karaginan tersebut. Gelombang ultrasonik akan memecah ikatan hidrogen pada polisakarida sehingga viskositas akan menurun.

\section{Karakteristik Bobot Molekul Karaginan Hasil Depolimerisasi}

Bobot molekul karaginan hasil depolimerisasi tertinggi terdapat pada perlakuan $\mathrm{H}_{2} \mathrm{O}_{2} 2 \%$ dengan suhu ultrasonikasi $40^{\circ} \mathrm{C}$ sebesar $45,43 \mathrm{kDa}$ sedangkan bobot molekul terendah terdapat pada perlakuan $\mathrm{H}_{2} \mathrm{O}_{2} \quad 6 \%$ dengan suhu ultrasonikasi $60^{\circ} \mathrm{C}$ sebesar 4,47 kDa (Gambar 3). Hasil analisis ragam menunjukkan bobot molekul karaginan hasil depolimerisasi dipengaruhi oleh suhu ultrasonikasi, konsentrasi $\mathrm{H}_{2} \mathrm{O}_{2}$ dan interaksi keduanya $(\mathrm{p}<0,05)$. Hasil uji lanjut Duncan menunjukkan bobot molekul karaginan hasil depolimerisasi dengan kombinasi perlakuan $\mathrm{H}_{2} \mathrm{O}_{2} 6 \%$ dan suhu ultrasonikasi $60^{\circ} \mathrm{C}$ berbeda nyata terhadap perlakuan lainnya.
Nilai bobot molekul yang menurun seiring dengan menurunnya viskositas diduga akibat perlakuan $\mathrm{H}_{2} \mathrm{O}_{2}$ dan suhu ultrasonikasi yang memutus ikatan polimer karaginan. Sun et al. (2009) menyatakan semakin tinggi konsentrasi $\mathrm{H}_{2} \mathrm{O}_{2}$ yang digunakan maka semakin rendah pula nilai bobot molekul karaginan tersebut. Penurunan nilai bobot molekul tersebut disebabkan semakin banyak radikal hidroksil reaktif $(-\mathrm{OH})$ yang terbentuk dari penguraian $\mathrm{H}_{2} \mathrm{O}_{2}$ akan memutus ikatan glikosidik dari polisakarida pada saat proses depolimerisasi. Ratnawati et al. (2016) menyatakan perlakuan suhu pada ultrasonikasi dapat menyebabkan uap dari pelarut masuk ke dalam rongga kavitasi yang terbentuk sehingga ikatan antar polimernya terurai.

\section{Perlakuan Depolimerisasi Karaginan Terpilih}

Perlakuan terpilih ditentukan melalui hasil analisis viskositas, bobot molekul hasil depolimerisasi karaginan dan melalui studi literatur penelitian. Viskositas dan bobot

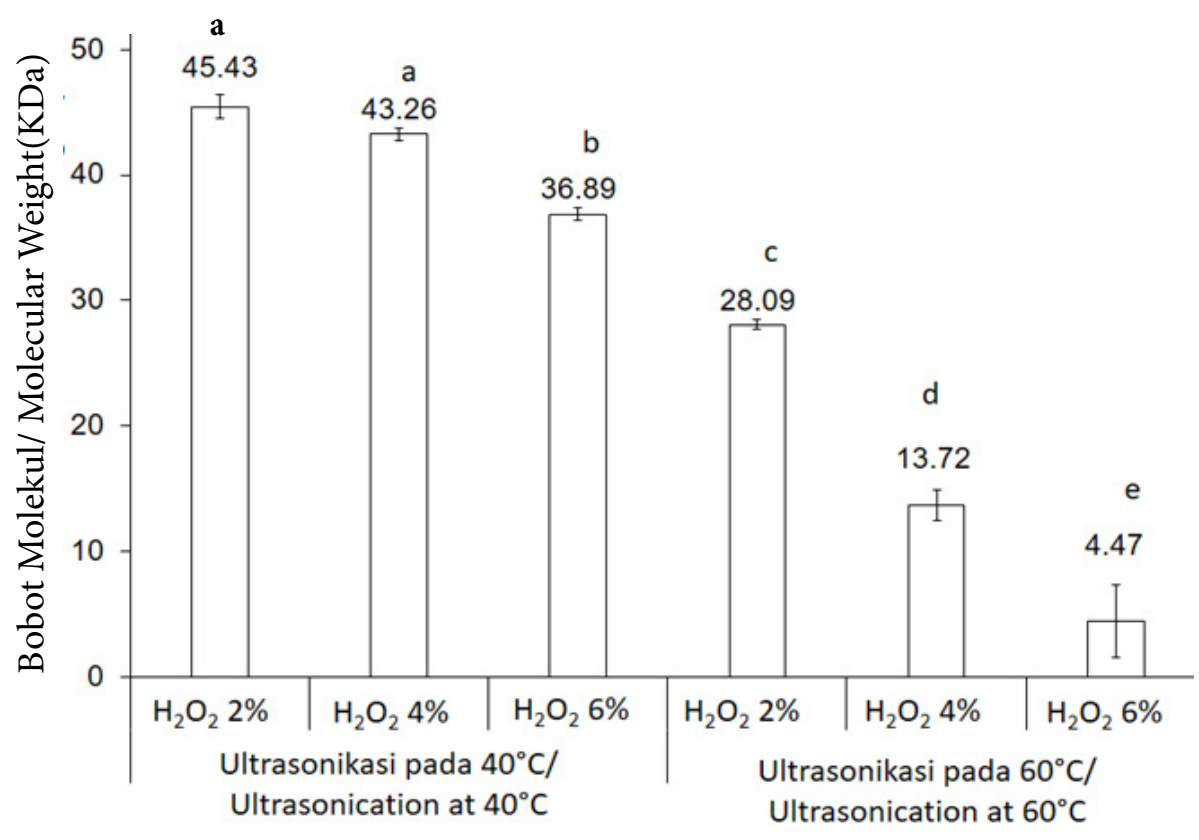

Gambar 3 Pengaruh suhu ultrasonikasi dan konsentrasi hidrogen peroksida terhadap bobot molekul karaginan yang depolimerisasi.

(Figure 3 Effect of ultrasonic temperature and hydrogen peroxide concentration on the depolymerized carrageer molecular weight). 
molekul depolimerisasi karaginan terpilih dihasilkan dari karaginan dengan perlakuan suhu ultrasonikasi $60^{\circ} \mathrm{C}$ dan $\mathrm{H}_{2} \mathrm{O}_{2} 6 \%$. Hasil tersebut medekati bobot molekul karaginan hasil depolimerisasi yang dilaporkan Kalitnik et al. (2013) yaitu 2,2 kDa.

Karaginan dari hasil depolimerisasi selanjutnya dilakukan analisis kadar abu tak larut asam, kadar sulfat dan analisis gugus fungsi menggunakan FTIR. Analisis lanjutan terhadap perlakuan terpilih depolimerisasi karaginan tersebut kemudian dibandingkan dengan dua perlakuan kontrol dan karaginan murni. Perlakuan kontrol yang pertama yaitu menggunakan larutan $\mathrm{H}_{2} \mathrm{O}_{2} 6 \%$ dan perlakuan kontrol kedua yaitu menggunakan suhu ultrasonikasi $60^{\circ} \mathrm{C}$.

\section{Karakteristik Kadar Abu Tak Larut Asam dan Kadar Sulfat Karaginan Perlakuan Terpilih}

Abu tidak larut asam adalah garam-garam klorida yang tidak larut asam yang sebagian adalah garam-garam logam berat dan silika (Wenno et al. 2012). Hasil kadar abu tak larut asam berkisar antara 0,11-0,18\% (Tabel 2). Hasil analisis ragam menunjukkan kadar abu tak larut asam perlakuan terpilih berbeda signifikan dengan karaginan murni, kontrol suhu ultrasonikasi $60^{\circ} \mathrm{C}$ dan kontrol $\mathrm{H}_{2} \mathrm{O}_{2} 6 \%$ $(\mathrm{p}<0,05)$. Uji lanjut Duncan menunjukkan abu tak larut asam berbeda nyata dengan karaginan murni tanpa perlakuan dan kontrol lainnya. Hasil kadar abu tak larut asam sudah sesuai dengan standard FAO (2007) maksimal sebesar 1\%. Hasil yang didapat lebih rendah daripada penelitian Chan et al. (2013) yang menunjukkan kadar abu tak larut asam karaginan berkisar antara $0,14-0,35 \%$. Hasil yang didapat diduga karena pada suhu tinggi zat-zat organik dan anorganik tak larut asam yang terdapat dalam karaginan dapat tereduksi secara optimal (Arfini 2011).

Kadar sulfat perlakuan terpilih (KP) didapat sebesar 18,24\%. Hasil analisis ragam menunjukkan kadar sulfat perlakuan terpilih berbeda signifikan dengan karaginan murni, kontrol suhu ultrasonikasi $60^{\circ} \mathrm{C}$ dan kontrol $\mathrm{H}_{2} \mathrm{O}_{2} 6 \%(\mathrm{p}<0,05)$. Uji lanjut Duncan menunjukkan kadar sulfat berbeda nyata dengan karaginan murni tanpa perlakuan dan kontrol suhu ultrasonikasi $60^{\circ} \mathrm{C}$ namun tidak berbeda nyata dengan kontrol $\mathrm{H}_{2} \mathrm{O}_{2} 6 \%$. Kadar sulfat yang didapat tidak sesuai dengan Campo et al. (2009) yang menyatakan semakin tinggi kadar sulfat maka semakin tinggi pula viskositas larutan tersebut. Kadar sulfat yang tidak berubah setelah diberi perlakuan dalam penelitian ini diduga karena tidak adanya perlakuan alkali dalam proses depolimerisasi sehingga perlakuan ultrasonikasi dan konsentrasi $\mathrm{H}_{2} \mathrm{O}_{2}$ hanya memecah ikatan glikosidik tanpa mengurangi kadar sulfat. Kasim (2013) menyatakan penggunaan alkali membantu monomer dengan membentuk 3,6-anhidrogalaktosa sehingga meningkatkan kekuatan gel.

Tabel 2 Perbandingan karaktersitik karaginan murni dan hasil depolimerisasi melalui beberapa metode depolimerisasi

(Table 2 Comparison of the characteristics of pure carrageen and depolymerization results through several depolymerization methods)

\begin{tabular}{ccc}
\hline \multirow{2}{*}{ Perlakuan/Treatment } & \multicolumn{2}{c}{ Parameter (\%) } \\
\cline { 2 - 3 } & Abu/Ash content & Sulfat/ Sulphate \\
\hline KM & $0.18 \pm 0.01^{\mathrm{a}}$ & $18.59 \pm 0.11^{\mathrm{a}}$ \\
KU & $0.17 \pm 0.01^{\mathrm{a}}$ & $17.83 \pm 0.25^{\mathrm{b}}$ \\
KK & $0.14 \pm 0.01^{\mathrm{ab}}$ & $18.25 \pm 0.02^{\mathrm{ab}}$ \\
KP & $0.11 \pm 0.02^{\mathrm{b}}$ & $18.24 \pm 0.13^{\mathrm{ab}}$ \\
\hline
\end{tabular}

Keterangan:

$\mathrm{KM}=$ Karaginan murni tanpa perlakuan depolimerisasi

$\mathrm{KU}=$ Karaginan murni dengan perlakuan ultrasonikasi pada suhu $60^{\circ} \mathrm{C}$

$\mathrm{KK}=$ Karaginan murni dengan perlakuan $\mathrm{H}_{2} \mathrm{O}_{2} 6 \%$ pada suhu $60^{\circ} \mathrm{C}$

$\mathrm{KP}=$ Karaginan perlakuan terpilih (ultrasonikasi pada suhu $60^{\circ} \mathrm{C}$ dengan $\mathrm{H}_{2} \mathrm{O}_{2} 6 \%$ ) 
Tabel 3 Data serapan karaginan murni

(Table 3 Data of pure carrageen adsorption)

\begin{tabular}{ccc}
\hline Bilangan gelombang/ wave number $\left(\mathrm{cm}^{-1}\right)$ & Ikatan/Bond & Gugus Fungsi/ Functional groups \\
\hline 1240 & $\mathrm{~S}=\mathrm{O}$ & ester sulfat $^{*}$ \\
970,72 & - & galaktosa $^{* *}$ \\
926,83 & C-O & 3,6 -anhidrogalaktosa \\
845 & C-O-S & 3,6 -anhidrogalakto-4-sulfat \\
\end{tabular}

Sumber: ${ }^{\star}$ Chopin dan Whalen (1993), ${ }^{* \star}$ Pereira (2009), ${ }^{* * \star S e k k a l ~ d a n ~ L e g r a n d ~(1993) ~}$

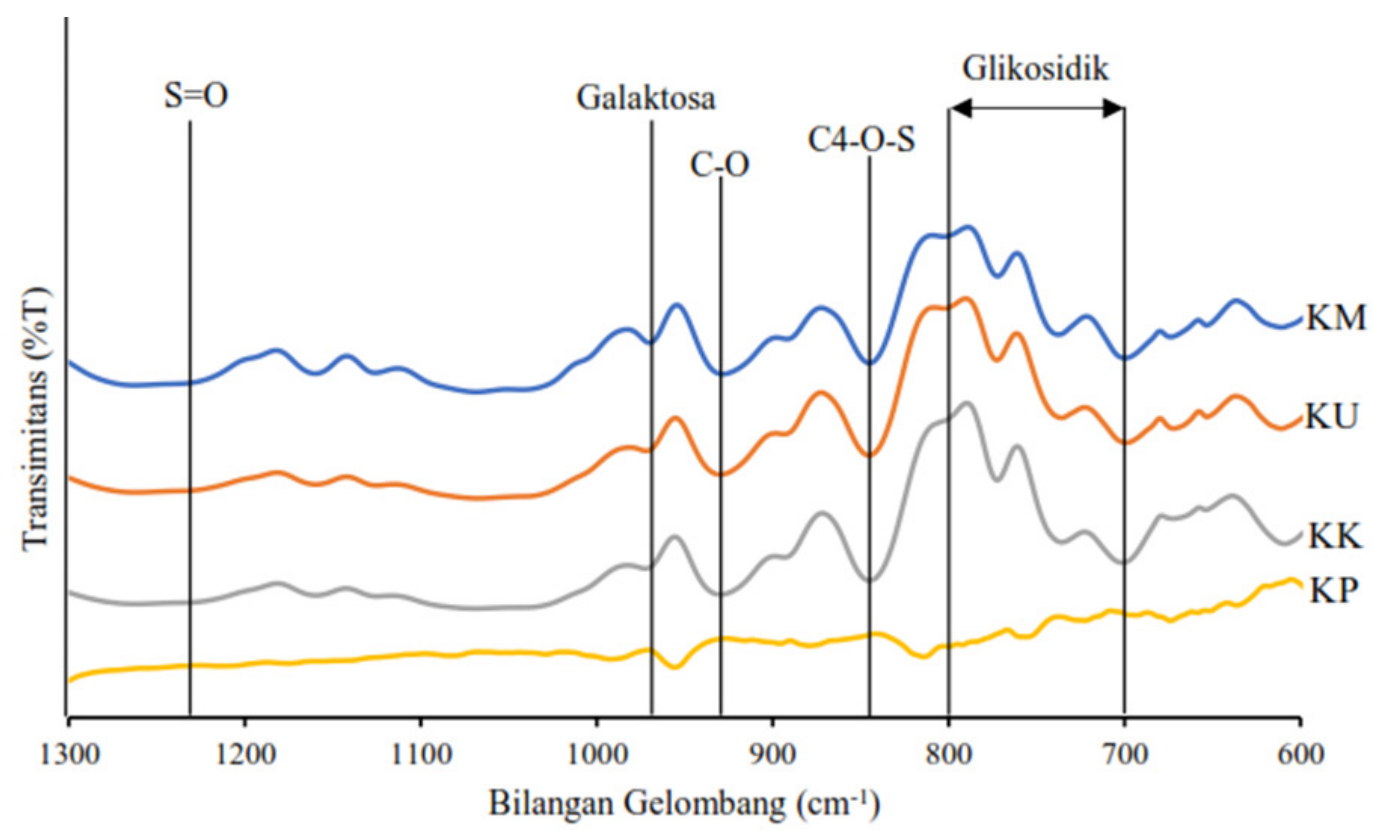

Gambar 4 Spektrum gugus fungsi hasil depolimerisasi karaginan. KM (karaginan murni tanpa perlakuan depolimerisasi), KU (karaginan murni dengan perlakuan ultrasonikasi pada suhu $60^{\circ} \mathrm{C}$ ), $\mathrm{KK}$ (karaginan murni dengan perlakuan $\mathrm{H}_{2} \mathrm{O}_{2} 6 \%$ pada suhu $60^{\circ} \mathrm{C}$ ), KP (karaginan perlakuan terpilih (ultrasonikasi pada suhu $60^{\circ} \mathrm{C}$ dengan $\left.\mathrm{H}_{2} \mathrm{O}_{2} 6 \%\right)$.

(Figure 4 Spectrum of functional groups of carrabinized depolymerization results)

\section{Karakteristik Gugus Fungsi Karaginan Perlakuan Terpilih}

Analisis perubahan gugus fungsi karaginan munrni dan karaginan hasil depolimerisasi dilakukan menggunakan Fourier Transform Infra Red Spectroscopy (FTIR). Hasil spektrum gugus fungsi karaginan murni dan hasil depolimerisasi dapat dilihat pada Gambar 4, sedangkan penjelasan tentang gugus fungsi karaginan hasil identifikasi dengan spektroskopi infra merah dapat dilihat pada Tabel 3.

Gambar 4 menunjukkan bahwa sampel karaginan murni yang digunakan berasal dari jenis kappa karginan. Hal tersebut teridentifikasi dari adanya gugus fungsi ester sulfat yang lebar, gugus fungsi galaktosa dan gugus 3,6-anhidrogalaktosa yang kuat yang merupakan karakteristik dari kappa karaginan (Pereira 2009). Karaginan murni tanpa depolimerisasi (KM) jika dibandingkan dengan dan karaginan murni hasil depolimerisasi $\mathrm{KU}$ dan $\mathrm{KK}$, karaginan hasil perlakuan terpilih (KP) memiliki kemunculan gugus fungsi yang sangat berbeda yang menunjukkan proses depolimerisasi telah terjadi. Perlakuan KP terlihat adanya pergeseran bilangan gelombang dari ikatan $\alpha(1,3)$ dan $\beta(1,4)$ glikosidik antara bilangan gelombang $700-800 \mathrm{~cm}^{-1}$ serta gugus 
3,6-anhidrogalakto-4-sulfat pada bilangan gelombang $845 \mathrm{~cm}^{-1}$ atau kemunculan intesitas cendrerung berkurang. Hal tersebut diduga bahwa pengaruh perlakuan depolimerisasi berhasil memutus ikatan glikosidik yang ada pada karaginan murni dan pada perlakuan ultrasonikasi pada suhu $60^{\circ} \mathrm{C}$ dengan $\mathrm{H}_{2} \mathrm{O}_{2} 6 \%$ (KP) terjadi sangat kuat.

\section{KESIMPULAN}

Perlakuan depolimerisasi karaginan dengan kombinasi $\mathrm{H}_{2} \mathrm{O}_{2}$ dan suhu ultrasonikasi memberi pengaruh terhadap karakteristik rendemen, viskositas dan bobot molekul karaginan murni. Karaginan terpilih dari kombinasi perlakuan tersebut diperoleh dari perlakuan $\mathrm{H}_{2} \mathrm{O}_{2} 6 \%$ dan suhu ultrasonikasi $60^{\circ} \mathrm{C}$. Karakteristik karaginan berbobot molekul rendah perlakuan terpilih memiliki kadar abu larut asam yang lebih rendah serta memiliki perubahan gugus fungsional yang sangat berbeda dengan perlakuan lainnya yang menunjukkan proses depolimerisasi telah terjadi.

\section{DAFTAR PUSTAKA}

Abad LV, Kudo H, Saiki S, Nagasawa N, Tamada M, Katsamura Y, Aranilla CT, Relleve Ls, De La Rosa AM. 2009. Radiation degradation studies of carrageenans. Carbohydrate Polymers. 78: 100-106.

Agustin TI. 2012. Mutu fisik dan mikrostruktur kamaboko ikan kurisi (Nemipterus nematophorus) dengan penambahan karaginan. Jurnal Pengolahan Hasil Perikanan Indonesia. 15(1): 17-26.

Angka SL, Suhartono MT. 2000. Bioteknologi Hasil Laut. Bogor (ID): Pusat Kajian Sumberdaya Pesisir dan Lautan, Institut Pertanian Bogor.

Arfini F. 2011. Optimasi proses ekstraksi pembuatan karaginan dari rumput laut merah (Eucheuma cottonii) serta aplikasinya sebagai penstabil pada sirup markisa [tesis]. Bogor (ID): Institut Pertanian Bogor.

Campo VL, Kawano DF, Junior DBS, Carvalho II. 2009. Carrageenans: biological properties, chemical modification and structural analysis. Carbohydrate Polymers. 77: 167-180.
Chan S W, Mirhosseini H, Taip F S, Ling T C, Tan C P. 2013. Comparative study on the physicochemical properties of k-carrageenan extracted from Kappaphycus alvarezii (doty) doty ex silva in Tawau, Sabah, Malaysia and commercial K-carrageenan. Food Hydrocolloids. 30: 581-588.

Chopin T, Whalen E. 1993. A new and rapid method for carrageenan identification by FTIR diffuse reflectance spectroscopy directly on dried, groind algal material. Carbohydrate Research. 246: 51-59.

Diharmi A, Fardiaz D, Andarwulan N, Herawati D. 2011. Karakteristik karaginan hasil isolasi Eucheuma spinosum (alga merah) dari perairan Sumenep, Madura. Jurnal Perikanan dan Kelautan. 16(1): 117-124.

Distantina S, Wiratni, Fahrurrozi M, Rochmadi. 2011. Carrageenan properties extracted from Eucheuma cottoni, Indonesia. World Academy of Science, Engineering and Technology. 54: 738-741.

Ega L, Lopulalan C G C, Meiyasa F. 2016. Kajian mutu karaginan rumput laut Eucheuma cottonii berdasarkan sifat fisiko-kimia pada tingkat konsentrasi kalium hidroksida $(\mathrm{KOH})$ yang berbeda. Jurnal Aplikasi Teknologi Pangan. 5(2): 38 $-44$.

[FAO] Food Agricultural Organization. 1990. Training Manual on Gracilaria Culture and Seaweed Processing in China: Department of Aquatic Products. Ministry of Agriculture, China. http:// www.fao.org/docrep/field/003/AB730E/ AB730E00.htm

[FAO] Food and Agriculture Organization. 2007. Compendium of Food Additive Specification, Joint FAO/WHO Expert Committee on Food Additives Monographs 4. Rome (IT): Food and Agriculture Organization of the United Nations.

[FMC Corp.] Food Marine Colloids Corporation. 1977. Carrageenan. Marine Colloid Monograph Number One. Springfield New Jersey (US): Marine Colloid Division FMC Corporation page 23-29 New Jersey. 
Fuadi A. 2012. Ultrasonik sebagai alat bantu ekstraksi oleoresin jahe. Jurnal Teknologi. 12(1): 14-21.

Haijin M, Xiaolu J, Huashi G. 2003. A k-carrageenan derived oligosaccharide prepared by enzymatic degradation containing anti-tumor activity. Journal of Applied Phycology. 15: 297-303.

Jacoeb AM, Nugraha R, Utari SPSD. 2014. Pembuatan edible film dari pati buah lindur dengan penambahan gliserol dan karaginan. Jurnal pengolahan Hasil Perikanan Indonesia. 17(1): 21.

Kalitnik AA, Barabanova AOB, Nagorskaya VP, Reunov AV, Glazunov VP, Solov'eva TF, Yermak IM. 2013. Low molecular weight derivatives of different carrageenan types and their antiviral activity. Journal of Applied Phycology. 25: 65-72.

Kasim S. 2013. Pengaruh konsentrasi natrium hidroksida terhadap rendemen karaginan yang diperoleh dari rumput laut jenis Eucheuma spinosum asal Kota Bau-Bau. Majalah Farmasi dan Farmakologi. 17(1): 1-8.

[KKP] Kementerian Kelautan dan Perikanan. 2015. Laporan Kinerja Kementerian Kelautan Dan Perikanan Tahun 2014. Jakarta (ID): KKP.

Li X, Xu A, Xie H, Yu W, Xie W, Maa X. 2010. Preparation of low molecular weight alginate by hydrogen peroxide depolymerization for tissue engineering. Carbohydrate Polymers. 9: 660-664.

Milani J, Maleki G. 2012. Hydrocolloids in food industry. Di dalam: Benjamin Valdez, editor. Food Industrial Processes Methods and Equipment. InTech.

Pereira L, Amado AM, Critchley AT, van de Velde F, Ribero-Claro PJA.2009. Identification of selected seaweed polysaccaharides (phycocolloids) by vibrational spectroscopy (FTIR-ATR and FT-Raman). Food Hydrocolloids. 23: 1903-1909.

Pomin VH. 2010. Structural and functional insights into sulfated galactans: a systematic review. Glycoconj Journal. 27: $1-12$.

Ratnawati R, Prasetyaningrum A, Wardhani D H. 2016. Kinetics and thermodynamics of ultrasound-assisted depolymerization of k-carrageenan. Bulletin of Chemical Reaction Engineering end Cataysis. 11(1): 48-58.

Sanchez JAV, Tagaya M dan Kobayashi T. 2013. Effect of ultrasound on the aqueous viscosity of several water-soluble polymers. Polymer Journal. 45: 12241223.

Savitri E, Juliastuti SR, Handaratri A, Sumarno, Roesyadi A. 2014. Degradation of chitosan by sonication in very-lowconcentration acetic acid. Polymer Degradation and Stability. 110: 344-352.

Sekkal M, Legrand P. 1993. A spectroscopic investigation of the carrageenans and agar in the $1500-100 \mathrm{~cm}^{-1}$ spectral range. Spectrochimica Acta. 49A(2): 209-221.

Sen M, Erboz E N. 2010. Determination of critical gelation conditions of $\mathrm{k}$-carrageenan by viscosimetric and FTIR analyses. Food Research International. 43:1361-1364.

Siregar R F, Santoso J, Uju. 2016. Karakteristik fisiko kimia kappa karaginan hasil degradasi menggunakan hidrogen peroksida. Jurnal Pengolahan Hasil Perikanan Indonesia. 19(3): 256-266.

Sun T, Tao H, Xie J, Zhang S, Xu Xian. 2009. Degradation and antioxidant activity of k-carrageenans. College of Food Science. 117: 194-199.

Sun $\mathrm{Y}$, Yang $\mathrm{B}, \mathrm{Wu} \mathrm{Y,} \mathrm{Gu} \mathrm{X,} \mathrm{Zhang} \mathrm{H}$, Wang C, Cao H, Huang L, Wang Z. 2015. Structural characterization and antioxidant activities of k-carrageenan oligosaccharides degraded by different methods. Food Chemistry. 178: 311-318.

Suptijah P, Suseno SH, Anwar C. 2013. Analisis kekuatan gel (gel strength) produk permen jelly dari gelatin kulit ikan cucut dengan penambahan karaginan dan rumput laut. Jurnal Pengolahan Hasil Perikanan Indonesia. 16(2): 183-191.

Tuvikene R, Truus K, Vaher M, Kailas T, Martin G, Kersen P. 2006. Extraction and quantification of hybrid carrageenans from the biomass of the red algae Furcellaria lumbricalis and Coccotylus truncatus. Proc. Estonian Acad. Sci. Chem.. 55(1):40-53. 
Uju. 2005. Kajian proses pemurnian dan pengkonsentrasian karaginan dengan membran mikrofiltrasi [tesis]. Bogor (ID): Institut Pertanian Bogor.

United Nations Commodity Trade Statistics Database. 2017. https://comtrade.un.org/ data/. [Diakses tanggal 18 Agustus 2017].

Walstra P. 2003. Physical Chemistry of Foods. New York (US): Marcel Dekker, Inc.

Wenno MR, Thenu JL, Lopulalan CGC. 2012. Karakteristik kappa karaginan dari Kappaphycus alvarezii pada berbagai umur panen. Jurnal Pascapanen dan
Bioteknologi Kelautan dan Perikanan. 7(1): 61-67.

Yu G, Guan H, Ioanoviciu AS, Sikkander SA, Thanawiroon C, Tobacman JK, Toida T, Linhardt RJ. 2002. Structural studies on k-carrageenan derived oligosacharides. Carbohydrate Research. 337: 433-440.

Yuan H, Song J. 2005. Preparation, structural characterization and in vitro antitumor activity of kappa-carrageenan oligosaccharide fraction from Kappaphycus striatum. Journal of Applied Phycology. 17: 7-13. 